\title{
Minapadi Trend, Need and Sustainability in Indonesia
}

\author{
Zaenal Arifim Siregar ${ }^{12^{*}}$, Sutrisno Anggoro ${ }^{3}$, Hari Eko Irianto and Hartuti Purnaweni ${ }^{1}$ \\ ${ }^{1}$ Department of Environmental Science, School of Doctoral Studies, Diponegoro University, \\ Semarang -Indonesia \\ ${ }^{2}$ Indonesian Research Institute for Fisheries Postharvest Mechanization, Ministry of Marine Affairs \\ and Fisheries, Bantul - Indonesia \\ ${ }^{3}$ Faculty of Fisheries and Marine Science, Diponegoro University, Semarang - Indonesia \\ ${ }^{4}$ Research Center and Development for Marine and Fisheries Product Processing and Biotechnology \\ (BBP4BKP), Ministry of Marine Affairs and Fisheries, Jakarta - Indonesia
}

\begin{abstract}
Abstrak. Technology created to simplify human's life. There amount of technology has been created. Current technology is the technology that used by humans from the past. Minapadi is technologies that has been created from the long time ago in agriculture and fisheries. Minapadi has existed in Indonesia since centuries ago. In past few years minapadi have become a trend in Indonesian article. This study literature conducted to study when minapadi become a trend and the urgency minapadi in Indonesia. Google scholar and Science Direct literature used in this literature study. This is to gather literature from Indonesian database, and for the comparison used literature from Science Direct. Minapadi used as keyword in Google Scholar, and in Science Direct used minapadi and "Rice Fish". In Indonesia there are an increase of minapadi article since 2016. It is dominated by economic study. Minapadi has the advantage of efficiency land for carbohydrate and protein production. Increase of number article minapadi shows an interest in minapadi. Meanwhile the growth of minapadi only increased by 48,083 hectares over 34 years. More research is needed to increase the use of minapadi, especially in the area adoption of technology, and environment for balancing the ecosystems.
\end{abstract}

Keyword: technology; minapadi; rice fish; trend.

\section{Introduction}

Technologies always create throughout human life. Technologies created to help and simplify human being. There is no exact amount of technology that have been made, both from simple technologies to complex technologies $[1,2]$. Many technologies used by human, but there's some of technologies cannot survive because not used in human life [3]. There is a lot of parameter to determine why someone used technology [4]. Simple technology or use

\footnotetext{
*Corresponding author: zaenalarifinsiregar@kkp.go.id
} 
full technology is not guarantee used by humans. The use of technology is affected by time [5]. Technology that is not used now, does not mean it is not used forever. Human need can change by in the future, and in that situation unused technologies can used if suits to human needs.

Agriculture and fisheries are some area that effected by technological developments. The growth of protein needs and carbohydrates needs, have to conduct with technology development in agriculture and fisheries. One of the technologies that has been created is Minapadi. Simple agricultural technology that utilizes land efficiently to produce carbohydrates and protein. The objective of Minapadi is to utilize space and time when planting paddy efficiently. In 2005, the method integrating fish and paddy have been included world's cultural heritage [6]. Minapadi has been in Indonesia for a long time. This method has many developments and some of development come from the farmers. It is necessary to learn about the existence of minapadi in Indonesia today.

Minapadi is studied based on database literature in Indonesia. This is done to find out when minapadi become a trend in Indonesian article. Studies are also used to classify themes that are discussed in the minapadi literature and existence of minapadi in Indonesia. The information obtained is used as a discussion of the urgency of Minapadi's existence in Indonesia and the challenge of Minapadi technology being applied in Indonesia.

The Studied consisted of 6 sections, which describes the background of the study and review of minapadi (part 1), method study (part 2), history of minapadi development in Indonesia (part 3), urgency of minapadi in Indonesia (part 4), challenges and issue of minapadi in Indonesia (section 5), and conclusions of studies (section 6).

\section{Method}

This study was conducted to review trends and chalangges of minapadi in Indonesia. Objective of this study are to find out when minapadi become tren in Indonesian article and to describe the urgency of minapadi in Indonesia. Google Scholar (GS) and Science Direct (SD) used to gather the article of minapadi. GS used to find out the literature from Indonesian database, and SD used as a comparison. Minapadi is the keywords in GS, while in SD used minapadi and "Rice Fish". The result selected based on criteria literature discusses about integrated fish and paddy. This done to minimize bias on the search results. From these results be searched the dominant themes in minapadi. The guidelines were acquired from the studies literature for selection criteria [7], methodology and article structure [8,9].

\section{Discussion}

\subsection{History of minapadi development in Indonesia}

The earlier literature states that the culture of integrating fish in rice fields has existed since the mid-19th century (in Cianjur, Singaparna, West Java), in Purwokerto and Muntilan around 1924, in Sumatra (1930), Manado (1897), Bali and Lombok around 1935 [10]. Minapadi in Indonesia was inseparable from Chinese immigrants, that's technology had existed in China around the Han dynasty century [11, 12]. In 1993, has been seminar to discuss the integration of fish and rice fields in Indonesia [13]. The expansion of integrated rice fish has propagation throughout Asia. Table 1 is a summary of the data distribution of types system integrated rice fish technology in Asia. In Indonesia have a minapadi which is a sub of integrated rice fish technology [14]. 
Table 1. Rice-Fish in Asia

\begin{tabular}{|c|c|c|c|c|c|}
\hline Country & Environment/System & $\begin{array}{c}\text { Rice } \\
\text { Variet } \\
\mathbf{y} \\
\end{array}$ & $\begin{array}{l}\text { Rice } \\
\text { Yield } \\
\text { (t/ha) }\end{array}$ & Fish Species & $\begin{array}{c}\text { Fish } \\
\text { Yield } \\
\text { (kg/ha) }\end{array}$ \\
\hline Bangladesh & $\begin{array}{l}\text { Freshwater culture } \\
\text { concurrent, Freshwater } \\
\text { culture concurrent on } \\
\text { station, Freshwater } \\
\text { culture concurrent with } \\
\text { feeding, Freshwater } \\
\text { culture concurrent on } \\
\text { farm, brackish water- } \\
\text { freshwater rotational, } \\
\text { brackish water- } \\
\text { freshwater rotational } \\
\text { concurrent }\end{array}$ & $\begin{array}{l}\text { aman, } \\
\text { boro, } \\
\text { BR } 11\end{array}$ & $\begin{array}{l}0.5- \\
7.7\end{array}$ & $\begin{array}{l}\text { Indian major } \\
\text { carps, } \\
\text { Heteropneusie } \\
\text { s fossilis, } \\
\text { P.gonionotus, } \\
\text { Oreochromis } \\
\text { niloticus, } \\
\text { P.monodon, } \\
\text { M. } \\
\text { rosenbergii, H. } \\
\text { molitrix, } \\
\text { Indian major } \\
\text { carps }\end{array}$ & $43-856$ \\
\hline China & $\begin{array}{l}\text { Freshwater culture (field- } \\
\text { pond/double rice, } \\
\text { ridged/single rice, rice- } \\
\text { azzola-fish (non- } \\
\text { ridged/double rice, non- } \\
\text { ridged/single rice), rice- } \\
\text { fish rotation in } \\
\text { swampland/single rice, } \\
\text { concurrent/ridge ditch } \\
\text { (on-farm/experimental, } \\
\text { on-station/species } \\
\text { composition), } \\
\text { concurrent/hatchery) }\end{array}$ & $\begin{array}{l}\text { early, } \\
\text { median } \\
\text {, late }\end{array}$ & $\begin{array}{l}3.3- \\
11.4\end{array}$ & $\begin{array}{l}\text { C.idella, } \\
\text { crucian carp, } \\
\text { C. carpio }\end{array}$ & $117-1896$ \\
\hline India & $\begin{array}{l}\text { Freshwater } \\
\text { ((irrigated/wetland, } \\
\text { Deepwater, valley fields, } \\
\text { beels), } \\
\text { concurrent/rainfed(captur } \\
\text { e/river basin, inland, } \\
\text { waterlogged), terrace } \\
\text { shallow/wild feeding, } \\
\text { pest control/low stocking } \\
\text { rate (irrigated, shallow } \\
\text { (hatchling to fingerlings, } \\
\text { growout (no feeding, } \\
\text { with feeding)))), } \\
\text { Brackish water } \\
\text { (traditional (pokkali, } \\
\text { khazan, bhasabadha/wild } \\
\text { cropping) modified } \\
\text { (pokkali, bhasabadha, }\end{array}$ & $\begin{array}{l}\text { moder } \\
\text { n, } \\
\text { deepw } \\
\text { ater } \\
\text { rice, } \\
\text { traditio } \\
\text { nal, } \\
\text { Ratna, } \\
\text { Pankaj, } \\
\text { Jaya, } \\
\text { salt- } \\
\text { resista } \\
\text { nt } \\
\text { local, } \\
\text { salt } \\
\text { resista } \\
\text { nt } \\
\text { moder }\end{array}$ & $\begin{array}{l}0.3- \\
6.4\end{array}$ & $\begin{array}{l}\text { murrels, } \\
\text { catfish, carps, } \\
\text { indian major } \\
\text { and Chinese } \\
\text { carps, natural } \\
\text { stock, wild } \\
\text { stocks, } \\
\text { C.carpio, C. } \\
\text { Striata, O. } \\
\text { mossambicus, } \\
\text { Cirrhinus } \\
\text { mrigala, L. } \\
\text { rohita, m. } \\
\text { rosenbergii, H. } \\
\text { fossilis, C. } \\
\text { batrachus, } \\
\text { metapenaeus } \\
\text { spp., penaeus } \\
\end{array}$ & $\begin{array}{l}\text { highly } \\
\text { variable }\end{array}$ \\
\hline
\end{tabular}




\begin{tabular}{|c|c|c|c|c|c|}
\hline Country & Environment/System & $\begin{array}{c}\text { Rice } \\
\text { Variet } \\
\mathbf{y}\end{array}$ & $\begin{array}{l}\text { Rice } \\
\text { Yield } \\
\text { (t/ha) }\end{array}$ & Fish Species & $\begin{array}{c}\text { Fish } \\
\text { Yield } \\
\text { (kg/ha) }\end{array}$ \\
\hline & $\begin{array}{l}\text { shallow, grow out on } \\
\text { farm, experimental) }\end{array}$ & $\begin{array}{l}\text { n, CRS } \\
1, \text { CSR } \\
3, \text { SR } \\
26 \mathrm{~B}, \\
\text { CR } \\
1014, \\
\text { Jaladhi } \\
\text {, NC } \\
492 \\
\text { Sabita }\end{array}$ & & $\begin{array}{l}\text { spp, m. ruide, } \\
\text { shrimp }\end{array}$ & \\
\hline Indonesia & $\begin{array}{l}\text { Freshwater/irrigate/concu } \\
\text { rrent ((on station rice fish } \\
\text { duck), on-farm } \\
\text { (minapadi-penyelang- } \\
\text { minapadi, rice palawija, } \\
\text { minapadi-penyelang- } \\
\text { palawija- } \\
\text { minapadi=penyelang- } \\
\text { vegetable-penyelang rice } \\
\text { field pond, combination } \\
\text { rice-fish-duck)) Coastal } \\
\text { freshwater rotational }\end{array}$ & IR 64 & $\begin{array}{l}3.2- \\
13\end{array}$ & $\begin{array}{l}\text { C.carpio, } \\
\text { milkfish, java } \\
\text { carp, tilapia, } \\
\text { m. } \\
\text { rosenbergii, } \\
\text { marine shrimp }\end{array}$ & $10-1600$ \\
\hline Korea & $\begin{array}{l}\text { Freshwater, concurrent, } \\
\text { with feeding }\end{array}$ & n.g & n.g & $\begin{array}{l}\text { Misgurnus } \\
\text { anguillicaudat } \\
\text { us, Parasilurus } \\
\text { asotus, O. } \\
\text { niloticus }\end{array}$ & $\begin{array}{l}1210- \\
2720\end{array}$ \\
\hline Malaysia & $\begin{array}{l}\text { Freshwater, capture, } \\
\text { sump single rice crop }\end{array}$ & n.g & n.g & $\begin{array}{l}\text { Trichogasler } \\
\text { pectoralis, T. } \\
\text { trichoplerus, } \\
\text { C. } \\
\text { macroephalus, } \\
\text { C. Striata, } \\
\text { Anabas } \\
\text { testudineus }\end{array}$ & $88-470$ \\
\hline Philippines & $\begin{array}{l}\text { Freshwter culture on- } \\
\text { farm, pond (with } \\
\text { fertilizer, animal } \\
\text { manure), trench (with } \\
\text { fertilizer, animal } \\
\text { manure), on station } \\
\text { (concurrent, rotational } \\
\text { (border planting pattern, } \\
\text { trench or pond refuge, } \\
\text { animal manure)) }\end{array}$ & $\begin{array}{l}\text { traditio } \\
\text { nal, } \\
\text { mount } \\
\text { ain, } \\
\text { IRRI } \\
\text { varieti } \\
\text { es, IR } \\
64\end{array}$ & $\begin{array}{l}1.5- \\
6.8\end{array}$ & $\begin{array}{l}\text { m.anguillicaud } \\
\text { atus, C. } \\
\text { carpio, O. } \\
\text { niloticus }\end{array}$ & $27-629$ \\
\hline
\end{tabular}




\begin{tabular}{|c|c|c|c|c|c|}
\hline Country & Environment/System & $\begin{array}{c}\text { Rice } \\
\text { Variet } \\
\mathbf{y} \\
\end{array}$ & $\begin{array}{l}\text { Rice } \\
\text { Yield } \\
\text { (t/ha) }\end{array}$ & Fish Species & $\begin{array}{c}\text { Fish } \\
\text { Yield } \\
\text { (kg/ha) }\end{array}$ \\
\hline Thailand & $\begin{array}{l}\text { Freshwater/rainfed } \\
\text { concurrent ((trap sump, } \\
\text { terraced field, open dike), } \\
\text { Kho Khad (Amnart } \\
\text { Caroen, Kheuang Nai, } \\
\text { Det Udom)), Freshwater } \\
\text { closed dike (rainfed } \\
\text { concurrent, irrigated } \\
\text { concurrent, irrigated } \\
\text { rotational, Deepwater, } \\
\text { Dom Noi/irrigated and } \\
\text { rainfed) }\end{array}$ & $\begin{array}{l}\text { rainfed } \\
\text { rice, } \\
\text { high } \\
\text { yieldin } \\
\text { g, RD } \\
6, \\
\text { RD8, } \\
\text { SPT, } \\
\text { KDML } \\
105, \\
\text { native }\end{array}$ & $1.2-3$ & $\begin{array}{l}\text { wild species, } \\
\text { C. carpio, P. } \\
\text { gonionotus, } \\
\text { tilapia, } \\
\text { Aristichthya } \\
\text { nobilis, } \\
\text { Trichogaster } \\
\text { sp. }\end{array}$ & $8-1875$ \\
\hline Vietnam & $\begin{array}{l}\text { Freshwater concurrent } \\
\text { (rice-shrimp), Brackish } \\
\text { water-freshwater } \\
\text { rotational (rice-shrimp) } \\
\text { Brackish water rotational } \\
\text { fish-shrimp-rice-fish }\end{array}$ & $\begin{array}{l}\text { dry } \\
\text { season, } \\
\text { wet } \\
\text { season, } \\
\text { traditio } \\
\text { nal, } \\
\text { wet } \\
\text { and } \\
\text { dry, } \\
\text { season, } \\
\text { Khmer } \\
\text { do, IR } \\
42\end{array}$ & $\begin{array}{l}2.4- \\
5.7\end{array}$ & $\begin{array}{l}\text { Metapenaeus } \\
\text { lysianassa, M. } \\
\text { tenuipes, M. } \\
\text { ensis, Penaeus } \\
\text { indicus, } \\
\text { Pseudapocrypt } \\
\text { es lanceolatus }\end{array}$ & $\begin{array}{l}50-80,2- \\
3 \mathrm{~kg} \\
\text { shrimp } / \mathrm{d} \\
\text { ay }\end{array}$ \\
\hline
\end{tabular}

Source[15]

$\mathrm{n} . \mathrm{g}=$ not given

Technology of Integration fish and rice field has several kinds in Indonesia. There are 5 types of integrated fish rice field technology, they are nurture the fish along with rice-paddy (Rice-Cum-Fish / RCF), fish cultivated after paddy has been harvested (during waiting time for rice planting, Rotational Fish / ROTF / tenders), fish cultivated during the paddy nursery period (Sequential Fish System / SEQF), fish cultivated during paddy nurseries and grown up with paddy until paddy harvested (Sequential Fish and Rice-Cum-Fish / SEQF RCF), and fish grown up with paddy twice as long as paddy is not harvested (Rice Cum Fish with Two Times of Fish Stocking / RCF2STCK) [14, 15]. Out Of 5 types integrated fish and rice field technologies that called in minapadi are RCF, SEQ RCF, and RCF2STCK. This is based on the continued nurture of fish in the paddy planting process. Commonly tawes, ikan mas, and nila are types of fish cultivated in Indonesia.

Minapadi has been in Indonesia for a long time but it has not adopted well by farmers. In 1974-1979, rice fields that used the Minapadi method were decrease [18]. Then in the past few years, the technology of integrated fish and rice field has attracted farmers' attention again because it promises economic benefits $[9,19]$. This was also can find out on the increase yield of fish consumption, in 1955 around 0.1 tons per hectare [10], to 0.3-0.89 tons per hectare [17].

In the research field based on searches in GS, and SD there is a trend research about minapadi seen in Figure 1. There has been an increase in the number of articles on GS since 2016, but in 2019 there was a decline which could be due to the 2019 data not being updated. 
In SD, there only 2 articles in Minapadi's search results (journal at 1982 and 2016). The search results in SD improve after minapadi keyword was changed to "RICE FISH". The result multiply in the number of articles. In SD there has been an increasing trend since 1998, and at 2020 the number of articles has reached the highest and there is still the possibility of increasing.

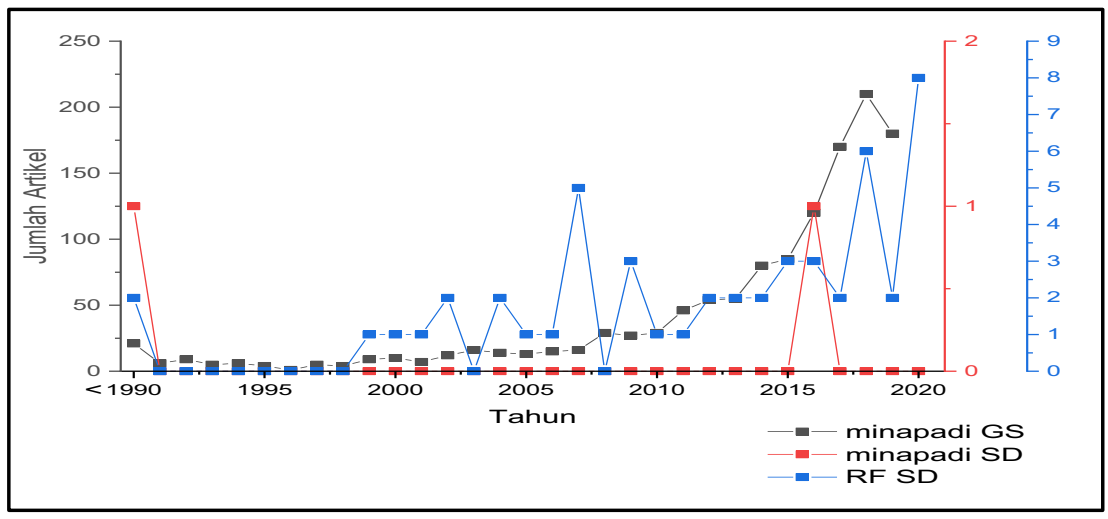

Fig. 1. Article in Google Scholar and Science Direct

At the time minapadi research has increased, that studies can be categorized on economic, technical (rice and fish), environmental, social and other themes. Discussions on economic themes consist of income comparisons, businesses analysis of monoculture and minapadi farmers' [20-27]. Technical theme discusses how to increase fish and rice production, attempt new fish and rice type in the minapadi [26-29]. On the environment theme, the related article analyses about the value of methane produced, impact of fertilizer application and ecological problems [30-32]. Many social themes concern to the adoption of farmers using Minapadi technology $[25,35,36]$. Another theme related to minapadi is food security $[35,36]$, counseling about minapadi [39].

\subsection{Urgency of minapadi in Indonesia}

Sustainable development is fusion between economic, social and environmental sectors [40]. Based on number of articles minapadi in past few year, the economic theme increasing higher than social and environmental articles theme. Social theme on technology adoption more intense than articles on the environment theme. Study about the effect of minapadi on the environment $[10,41]$ was have been done before the minapadi theme became a trend. Practice of minapadi technology is under expectation [25] needs more effort to increase the literature in the social sector mainly on the subject of adoption minapadi. this necessary to be done so that minapadi technology can become a sustainable technology.

Enhancement use of minapadi has eventuate in China, this is due to Chinese government regulations concerning the use of reservoir [9]. This can be happened in Indonesia in view of conflicts in the use of water for agriculture [42], energy, and drinking water. Alteration land use in Indonesia have taken place [43]. Land lessen for food production make remodelling monoculture land management to polyculture (make efficient use of existing land). This make minapadi adoption more urgent than several years ago. 


\subsection{Challenges and issue of minapadi in Indonesia}

Percentage of minapadi use in 1985 was $6 \%$ of the total paddy fields or 94,309 hectares [18], while in 2019 about $1 \%$ of the total paddy fields in Indonesia or 142,122 hectare [25]. An escalate in use of minapadi adjacent to 48,083 hectares over 34 years, but the percentage of number use minapadi in fields has decline. This can be described that the opening new fields is still not much using minapadi. There are some farmers no longer use minapadi by reason of lowering income, dependence on fertilizers and pesticides, and environment changes such as pest, and the subsidence of the rice field ridge [44]. This is issue for minapadi to become sustainable technology. It is necessary to multiply studies in the social field, especially the adoption of technology. The field of environment in balancing existing ecosystems is an essential, beside to study an increase in economic income due to the use of minapadi.

\section{Conclusions}

Minapadi has the advantage of efficiency land for carbohydrate and protein production. Since 2016 there has been an increase in articles about minapadi. This shows an interest in minapadi that has existed since centuries ago. There are many literatures on economic benefit theme as a study of minapadi use but in the growth of minapadi use has only increased 48,083 hectares over 34 years. Intensify the studies in the social field is an obligation, particularly the adoption of technology and environment for balancing existing ecosystems. There have been many changes in land use that can reduce of land for food production. It is necessary to accelerate the application of Minapadi to maintain food security, specifically carbohydrates and proteins.

\section{Acknowledgment}

This review study supported by Ministry of Marine Affairs and Fisheries Republic of Indonesia provide scholarships (Number. 26 / SJ / KP.532 / I / 2019), so this research can be done.

\section{References}

1. M. Muslimin, Perkembangan Teknologi Dalam Industri Media, J. Tek. Ind., 12, 1, p. 57 (2012).

2. M. Coccia and J. Watts, A theory of the evolution of technology: Technological parasitism and the implications for innovation magement, J.Eng. Technol. Manag. JET-M, 55, October 2018, p. 101552 (2020).

3. C. Shelton, Giving up technology and social media: why university lecturers stop using technology in teaching, Technol. Pedagog. Educ., 26, 3, pp. 303-321 (2017).

4. S. Altuntas, T. Dereli, and A. Kusiak, Forecasting technology success based on patent data, Technol. Forecast. Soc. Change, 96, pp. 202-214 (2015).

5. Y. Huang, A. L. Porter, Y. Zhang, X. Lian, and Y. Guo, An assessment of technology forecasting: Revisiting earlier analyses on dye-sensitized solar cells (DSSCs), Technol. Forecast. Soc. Change, 146, October 2018, pp. 831-843 (2019).

6. J. Lu and X. Li, Review of rice-fish-farming systems in China - One of the Globally Important Ingenious Agricultural Heritage Systems (GIAHS), Aquaculture, 260, 1-4, pp. 106-113 (2006).

7. E. Aivazidou, N. Tsolakis, E. Iakovou, and D. Vlachos, The emerging role of water footprint in supply chain management: A critical literature synthesis and a hierarchical 
decision-making framework, J. Clean. Prod., 137, pp. 1018-1037 (2016).

8. W. Leal Filho, S. Raath, B. Lazzarini, V. R. Vargas, L. de Souza, R. Anholon, O. L. G. Quelhas, R. Haddad, M. Klavins, and V. L. Orlovic, The role of transformation in learning and education for sustainability, J. Clean. Prod., 199, pp. 286-295 (2018).

9. M. A. Bashir, J. Liu, Y. Geng, H. Wang, J. Pan, D. Zhang, A. Rehim, M. Aon, and H. Liu, Co-culture of rice and aquatic animals: An integrated system to achieve production and environmental sustainability, J. Clean. Prod., 249, p. 119310 (2020).

10. R. O. Ardiwinata, Fish Culture on Paddy Fields in Indonesia, Proc. Indo-Pacific Fish, 7, II-III, pp. 119-154 (1957).

11. S. K. Saikia and D. N. Das, Sustainable aquaculture: agro-ecological role of periphyton in ricefish farming, Rev. Aquac., 7, 3, pp. 172-186 (2015).

12. Q. Wang, L. Cheng, J. Liu, Z. Li, S. Xie, and S. S. De Silva, Freshwater aquaculture in PR China: trends and prospects, Rev. Aquac., 7, 4, pp. 283-302 (2015).

13. D. C. Little, P. Surintaraseree, and N. Innes-Taylor, Fish culture in rainfed rice fields of northeast Thailand, Aquaculture, 140, 4, pp. 295-321 (1996).

14. J. J. Sasa and O. Syahromi, Sistem Minapadi dalam Perspektif Produktivitas Lahan, Pendapatan, dan Lingkungan, Penelit. Pertan. Tanam. Pangan, 25, 2, pp. 135-143 (2006).

15. C. Lightfoot, B. A. Costa-Pierce, M. Bimbao, and C. dela Cruz, Introduction to RiceFIsh Research and Development in Asia, Rice-Fish Res. Dev. Asia, C. . dela Cruz, C. Lightfoot, B. . Costa-Pierce, V. . Carangal, and M. . Bimbao, Eds., International Center for Living Aquatic Resource Management (ICLARM), Manila, pp. 1-10 (1992).

16. M. Yunus, A. Hardjamulia, I. Syamsiah, and S. Suriapermana, Evaluation of Rice-Fish Production System in Indonesia, Rice-Fish Res. Dev. Asia, C. . dela Cruz, C. Lightfoot, B. . Costa-Pierce, V. . Carangal, and M. . Bimbao, Eds., International Center for Living Aquatic Resource Management (ICLARM), Manila, pp. 131-137 (1992).

17. E. Dwiyana and T. C. Mendoza, Comparative Productivity, Profitability and Efficiency of Rice Monoculture and Rice-Fish Culture Systems, J. Sustain. Agric., 29, 1, pp. 145166 (2006).

18. S. Koesoemadinata and B. A. Costa-Pierce, Development of Rice-Fish Farming in Indonesia: Past, Present dan Future, Rice-Fish Res. Dev. Asia, C. . dela Cruz, C. Lightfoot, B. . Costa-Pierce, V. . Carangal, and M. . Bimbao, Eds., International Center for Living Aquatic Resource Management (ICLARM), Manila, pp. 45-62 (1992).

19. A. Datta, D. R. Nayak, D. P. Sinhababu, and T. K. Adhya, Methane and nitrous oxide emissions from an integrated rainfed rice-fish farming system of Eastern India, Agric. Ecosyst. Environ., 129, 1-3, pp. 228-237 (2009).

20. A. Nurhayati, W. Lili, T. Herawati, and I. Riyantini, Derivatif Analysis of Economic and Social Aspect of Added Value Minapadi (Paddy-fish Integrative Farming) a Case Study in the Village of Sagaracipta Ciparay Sub District, Bandung West Java Province, Indonesia, Aquat. Procedia, 7, pp. 12-18 (2016).

21. A. Mardjudo and M. Yasin, Household Economic Model to Improve Small-Scale Fisherman Income at Rural Minapadi (Rice-Fish System) Development Program In Donggala, Central Sulawesi, Russ. J. Agric. Socio-Economic Sci., 70, 10, pp. 247-255 (2017).

22. M. N. Prasetyo, S. Hartono, and M. Masyhuri, The Analysis Of Business, Risk, And Development Strategy Of Minapadi (Paddy-Fish Integration Farming System) In Sleman District, Agro Ekon., 29, 1, p. 64 (2018). 
23. Sularno and S. Jauhari, Peluang Usaha Melalui Agribisnis Mina Padi Untuk Meningkatkan Pendapatan Petani, SEPA J. Sos. Ekon. Pertan. dan Agribisnis, 10, 2 , pp. 268-274 (2014).

24. M. Sauqie, T. Elfitasari, and S. Rejeki, Analisa Usaha Kegiatan Budidaya Minapadipada Kelompok Mina Makmur dan Kelompok Mina Murakabi di Kabupaten Sleman, J. Aquac. Manag. Technol., 6, 1, pp. 1-7 (2017).

25. Y. Syaukat and D. R. Julistia, Analysis of Income and Factors Determining the Adoption of Integrated Rice-Fish Farming System in Seyegan District, Sleman Regency, Yogyakarta, Indonesia, J. Int. Soc. Southeast Asian Agric. Sci., 25, 1, pp. 6679 (2019).

26. F. M. Ariska, Prospect of Development Agribusiness Creativity and Innovation, $J$. Peternak. (Jurnal Anim. Sci., 4, 1, pp. 46-52 (2020).

27. E. Sumarsih, R. S. Natawidjaja, and A. Silmi, Peningkatan Produksi Padi, Pendapatan dan Efisiensi Penggunaan Sumberdaya Melalui Penerapan Sistem Tanam Jajar Legowo Pada Minapadi, J. Penelit. Pertan. Tanam. Pangan, 4, 1, p. 35 (2020).

28. R. Lantarsih, Pengembangan "Minapadi Kolam Dalam" di Kabupaten Sleman, Agrar. J. Agribus. Rural Dev. Res., 2, 1, pp. 17-27 (2016).

29. N. Rozen, A. Anwar, and dan N. Kristina, Minapadi-Sri Pattern on Rice Cultivation with IR42 Varieties, Int. J. Environ. Agric. Biotechnol., 4, 5, pp. 1456-1461 (2019).

30. N. Rozen, A. Anwar, and N. Kristina, The Effect of Fish Type and Variety on Growth and Results Through the Application of Minapadi-SRI, IOP Conf. Ser. Earth Environ. Sci., 327, 1, p. 012023 (2019).

31. H. B. Nugroho, F. Basuki, and R. W. A, Pengaruh Padat Penebaran Yang Berbeda Terhadap Laju Pertumbuhan Ikan Nila (Oreochromis Niloticus, Linn. 1758) Pada Sistem Budidaya Minapadi, J. Aquac. Manag. Technol., 6, 2, pp. 21-30 (2017).

32. E. Mahmudiyah and R. Soedradjad, Pengaruh Pupuk Organik dan Teknik Budidaya Terhadap Produksi Padi dan Ikan Pada Sistem Mina Padi, Agritrop J. Ilmu-Ilmu Pertan. (Journal Agric. Sci., 16, 1, p. 17 (2018).

33. M. F. N. Wafa, Z. Hasan, I. Gumilar, and A. Sahidin, Plankton Community Structure and Its Relationship with Minerals Profiles in Minapadi Area, Talagasari Village, Kadungora Garut Regency, Asian J. Fish. Aquat. Res., 4, 2, pp. 1-13 (2019).

34. L. S. Supriatin, Penentuan Musim Tanam, Jenis Varietas, Dan Teknik Budidaya Tanaman Padi Terkait Mitigasi Emisi Metana (Ch4) (Determination Of Early Planting Season, Type Varieties, and Cultivation Techniques of Rice as Mitigation to Methane Emission), J. Mns. dan Lingkung., 24, 1, p. 1 (2017).

35. A. F. Septiana, Pujiharto, and S. Budiningsih, Kajian Adopsi Inovasi Pola Tanam Jajar Legowo Pada Usahatani Padi Sawah (Studi Kasus Pada Kelompok Tani Sekar Arum di Desa Pabuaran Kecamatan Salem Kabupaten Brebes), Agritech J. Fak. Pertan. Univ. Muhammadiyah Purwokerto, XVIII, 1, pp. 1-8 (2016).

36. N. Warda, M. Asaad, S. B. Sugiman, and Z. Abidin, Analisis Persepsi Petani Terhadap Penerapan Tanam Jajar Legowo Padi Sawah Di Sulawesi Tenggara, J. Pengkaj. dan Pengemb. Teknol. Pertan., 20, 3, pp. 197-208 (2018).

37. S. Lestari and A. Nur Bambang, Minapadi Development Strategy in Supporting National Food Security, E3S Web Conf., 31, pp. 1-4 (2018).

38. E. Djuwendah, T. Priyatna, K. Kusno, Y. Deliana, and E. Wulandari, Building agribusiness model of LEISA to achieve sustainable agriculture in Surian Subdistrict of Sumedang Regency West Java Indonesia, IOP Conf. Ser. Earth Environ. Sci., 142, 1, 
pp. 1-8 (2018).

39. Z. P. Rahmadi, A. Zuber, and M. Wijaya, Analisa Kasus Peran Penyuluh Swadaya Dalam Pengembangan Budidaya Minapadi di Desa Nogotirto, J. Anal. Sosiol., 1, 1, pp. 94-106 (2019).

40. G. H. Brundtland and M. Khalid, Our Common Future. World Commission on Environment and Development, Oxford University Press, New York (1987).

41. S. Koesoemadinata, Aquatic Toxicology of Selected Rice Insecticides, With Special Reference to Their Effects on Fish Culture In West Java, Indonesia, University of Stirling (1990).

42. S. Siswadi, T. Taruna, and H. Purnaweni, Kearifan Lokal Dalam Melestarikan Mata Air (Studi Kasus di Desa Purwogondo, Kecamatan Boja, Kabupaten Kendal), J. Ilmu Lingkung., 9, 2, p. 63 (2012).

43. H. Purnaweni, Kebijakan Pengelolaan Lingkungan di Kawasan Kendeng Utara Provinsi Jawa Tengah, J. Ilmu Lingkung., 12, 1, pp. 53-65 (2014).

44. S. H. Rosadi, Peralihan Usahatani Dari Mina Padi Ke Non Mina Padi (Kasus Petani di Desa Kalola, Kecamatan Maniangpajo, Kabupaten Wajo), Universitas Hasanudin (2015). 